\title{
The Effectiveness of Mosquito Breeding Site Eradication and Role of Wiggler Controller toward Countermeasure Effort of Dengue Hemorrhagic Fever in Klaten, Central Java
}

\author{
Riska Chandra Pradana'), Ruben Dharmawan², Endang Sutisna Sulaeman³) \\ 1)Dr. R Soeprapto Cepu Hospital, Central Java \\ 2)3)Faculty of Medicine, Universitas Sebelas Maret
}

\begin{abstract}
Background: Countermeasure of Dengue Hemorrhagic Fever (DHF) is more prioritizing in preventive activities such as implementing mosquito breeding site eradication or PSN through $3 \mathrm{M}$ plus by involving the society and facilitating the establishment of wiggler controllers or Jumantik. Role of wiggler controllers is very important especially in initial vigilance system moreover in the outbreaks of DHF because of their function in monitoring the wigglers' position and hampering the initial development of DHF transmitter vector. The activeness of wiggler controllers in monitoring their environment is expected to decrease the number of DHF cases. This study was aimed to investigate analyzing the effectiveness of mosquito breeding site eradication and the roles of wiggler controllers or Jumantik in prevention and countermeasure efforts of DHF.

Subjects and Method: This was a qualitative study with case study design conducted in Juwiring, Ngawen, North Klaten, Central Java. Community health center in Klaten, Central Java, was selected by purposive sampling. The data was collected by observation, in-depth interview, and document review. Data validity was checked by triangulation. The data was analyzed by data collection, reduction, and presentation.

Results: People did not do mosquito breeding site eradication (MBE). They lacked of knowledge about MBE. Health workers lacked of knowledge in MBE program. The role of public figure was not maximized. Health facilities and infrastructures were adequate to perform individual health effort in promotive, preventive, curative, or rehabilitative which were done by the government, regency government, or the society especially to encourage the implementation of MBE program. Amount of health officers for the implementation of MBE program was not ideal yet, especially for Epidemiology officers and Health Promotion officers. Public and government supports were quite good in the implementation of MBE program. Attitude and behavior of public figures, religious leaders, and also health officers were quite good. Although some of public figures did not give their full support. Government policy in encouraging the implementation of MBE itself was quite good. That was proven by publishing Region Regulation No. 03 of 2010 and Regent Regulation No. 05 of 2013 about prevention and disease control from animal sources, but its implementations were not maximum and binding yet. The role of wiggler controllers in decreasing the rate of DHF cases could be optimized by specific commitment from the policy makers, started from the highest to the lowest in order to build better initial vigilance system. Operational fund for the wiggler controllers (Jumantik) in Klaten District was not ideal yet, so, commonly they spent their own money for the operational fund when they did their job.

Conclusion: The effectiveness of MBE program in Klaten District to overcome DHF was effective enough. The role of predisposition factor toward MBE in order to overcome DHF in Klaten District was became the booster of the implementation of MBE program. Enabling Factors are enormously important in implementing the MBE program in the public. The encourage factor on MBE program was not maximum yet, especially in the implementation of Region Regulations and Regent Regulations particularly about Prevention and Disease Control from Animal Source. The roles of wiggler controllers in the countermeasure of DHF in Klaten District was very important especially for the initial vigilance of DHF because its functions were used to monitor their existences and also hamper the initial development of DHF transmitter vector.
\end{abstract}

Keywords: mosquito breeding site eradication, DHF, the role of wiggler controllers 
Journal of Epidemiology and Public Health (2016), 1(1): 37-48

https://doi.org/jepublichealth.2016.01.01.05

\section{Correspondence :}

Riska Chandra Pradana. Dr. R Soeprapto, Cepu Hospital, Central Java.

Email:pradanachan@gmail.com

\begin{abstract}
BACKGROUND
$\overline{\mathrm{DHF}}$ is an environmental-based disease.

Several factors influencing the increase of DHF cases are urban development, climate change, mobility improvement, population density, lack of community participation, and include weakness of control program and DHF control, so that DHF control effort and attention need attention especially at Regency / City and Puskesmas (Health Ministry, 2010).
\end{abstract}

Other factors that encourage the increasing cases of dengue fever are limited health workers to conduct continuous education and community awareness of efforts to prevent dengue through PSN. So it is necessary to increase the extension of health workers to the community both individuals, families, and societies (Soeparmanto, 2006).

DHF prevention efforts that have been done by Indonesia Republic Health Ministry are prioritized on preventive and promoted activities by mobilizing and empowering community in PSN effort. Intensive PSN activities have been implemented since 1992 and in 2002 developed into $3 \mathrm{M}$ Plus. The "3M plus" activity, which drains the water reservoir, closes the water reservoir, buries the used goods and sows larvae (larvasida), utilizes used goods, maintains larvae and others. $3 \mathrm{M}$ plus activities are also expanded by increasing community habits to use mosquito repellent (spray, burn, polish) to prevent mosquito bites, and avoid habit of hanging the house indoors clothing. The countermeasures have not been optimalyet. One of the causes of non-optimal effort of handling is because there is no changing community behavior in PSN effort (Director General of P2PL, Ministry of Health RI, 2009).

DHF prevention prioritizes preventive activities byimplementing PSN through $3 \mathrm{M}$, involving the community and facilitating the formation of jumantik personnel. To support the implementation of this program, a partnership is established through a Pokjanal vessel along with other cross sectors. In addition, there is counseling for the community to stay alert to DHF. The role of jumantik is very important in the early awareness system of DHF outbreaks because it serves to monitor the presence and inhibit early development of dengue vector transmissible. The activeness of jumantik cadres in doing PJB is expected to reduce the number of dengue cases. Therefore, it is necessary to increase jumantik activity through motivation done by health service (Yulianti, 2007).

Based on the background above, the authors will conduct study on the effectiveness of PSN program and the jumantik role in efforts of controlling DBD in Klaten. The objective of the study was to analyze the effectiveness of PSN program and the role of jumantik in preventing and controlling DBD in Klaten.

\section{SUBJECTS AND METHOD}

This was descriptive qualitative with case study method, a study used to understand a problem by emphasizing on depth and context description in detail or to identify case rich with information (Cresswell, 2010).

Sampling technique in this study used purposive sampling. Study was conducted Juwiring, Ngawen, and Klaten community health center, Klaten, Central Java. Infor- 
mant study in this study is determinant of policy, health officer and society. The health personnel involved as key informants are $\mathrm{P} 2 \mathrm{PC}$ coordinator, surveillance officer, health promotion field of community health center, village midwife, and P2DBD officer of puskesmas. Informants from the community were the village head, village coordinators, community leaders, FKD, PKK members, Jumantik, POKJANAL posyandu, and village health cadres as well as people who hador didn't have dengue fever. The policy-making informant is the head of community health center and the head of $\mathrm{P}_{2} \mathrm{P}$ field of Klaten health office.

Techniques used in processing data analysis used interactive analysis model. According Sulaeman (2015), data analysis techniques consisted of organizing data, grouping by category, theme and pattern answers, test assumptions or problems that existed on the data, looked for alternative explanation for the data and wrote report of study results.

\section{RESULT}

Theinformant characteristics used in this study included informants of health workers who were mostly over 35 years old with DIII degree, 2 informants with D4 degree and 1 informant with $\mathrm{S} 1$ degree. Community informants included Jumantik Cadres, PKK Mobilization Team, Health Cadres, community affected by DHF, healthy community, and community members of the Village Health Forum. Most of them were more than 40 years old and had high school education, 1 informant with $\mathrm{S} 1$, and 1 informant with junior high school. The policy-making informants in this study were P2P Division Head of Klaten Health Office, Head of P2B2 Health Office of Klaten, Head of community health center, Village Head, and Village Coordinators. Most of the policy-making informants were over 45 years old and had S1 degree, 2 informants had S2 degree, 1 informant had D1 and only 1 high school informant.

The interview results found that PSN program was the most effective program in preventing DHF in Klaten. This happened because by usning PSN, the mosquito larvae would die so that mosquito larva would not be able to turn into a mosquito carrying dengue virus. Unlike DBD prevention by fogging less effective in tackling DHF because fogging kills only adult mosquitoes without being able to kill mosquito larva to obtain maximum result. Mature mosquitoes would die but when the adult mosquitoes laid eggs and eggs became larvae then this larva did not necessarily die with fogging. Besides this fogging action was less effective because mosquitoes were resistant to fogging mosquitoes which were good at evaporating fogging smoke and mutations occurring mosquito genes becoming more resistant to fogging. Fogging action also had side effects on humans damaging the endocrine system, nerves and reproduction.

Based on the interview results to all health personnel informants obtained the results that health workers knew teoretically about the understanding of PSN which was an effort made either by the government, public, private or country to eliminate mosquito place misses, especially mosquitoes that could transmit dengue disease mosquito Aedes aegypti. The routine and simultaneous activities of PSN had to be done and involved all community members living in an environment not just 1 but 2 people.

Basically, all health worker informants and public knew about the understanding of PSN although in its implementation hadn't been optimal because public awareness still lacked on the implementation of PSN and society didnot 
Journal of Epidemiology and Public Health (2016), 1(1): 37-48

https://doi.org/jepublichealth.2016.01.01.05

routinely implement it. It was expected that by PSN program, morbidity rate (IR) of dengue disease could decrease from the previous year. Although PSN program had already run, but for this year there was an increase in morbidity rate (IR) DHF disease in Klaten.

The interviewresults to all health personnel informants obtained the result that health workers knew about the objectives of PSN program which was to free the community environment from dengue disease and suppress the incidence (IR) DBD and mortality rate (CFR) DBD although in its implementation there still was less than optimal. This happened because people were still unaware of the importance of PSN Program to prevent DHF and people considered that fogging was the most effective way to tackle DHF and the absence of ideal funding in the implementation of PSN Program in Klaten.

Based on the interview results with all informants of health personnel said that the output between the PSN program was ABJ reach $>95 \%$ so as to suppress the incidence of DHF, another hope was the community to maintain the cleanliness of its own environment, so by maintaining the environment PHBS became a community habit because with PHBS where the mosquito breeding was to free eggs and larvae of aedes aegypti mosquito. In addition, the community not only maintained cleanliness of the environment and did PSN only when there were dengue cases but routinely perform PSN at least once a week.

Based on the interview results could be explained that all health personnel informants understood the expected results of PSN program implementation. The expected outcome of PSN program was that IR decreased so that the morbidity and mortality from dengue fever also decreased. Other expected end result was dengue fever and the community had free larva. If larval behavior became a culture in the community, then little by little it would reduce the morbidity and mortality due to DBD. Based on the interview results with informants could be explained that the expected outcome compared with the results between (output) there was still a significant difference. This could be seen from ABJ which was expected to increase and reach $>95 \%$ but this year ABJ only 90\% increased compared to last year that ABJ only reached $80 \%$. The comparison between the expected outcome and the intermediate outcome was the expected DHF (IR) rate of $<20 / 100,000$ population. But for this year the results between the morbidity rate (IR) DBD reached 63/ 100,000 population increased than last year of 45/ 100,000 population.

Some factors that caused the number of morbidity (IR) DBD increased from last year included unstable climate, a lot rain in rainy season which is a potential breeding tool Aedes aegepty mosquitoes, wet and dry season happen in Indonesia, and not optimal PSN activities in the community. PSN program could affect the physical environment in community. Physical environmental factors affecting food and nutrition status of a region are weather, climate, soil conditions, cultivation systems, and environmental health. The expectation of PSN Program implementation was healthy environment and no dengue fever so that people will be healthy. Based on the interview results with all informants of health workers and the public said that DHF mortality rate in 2016 decreased compared to the previous year. In 2015 DHF rate reached $4.95 \%$ while in 2016 it dropped to 2.6\%. However, the mortality rate this year is still higher than the national target of $<1 \%$. This was caused by several factors namely public awareness of low PSN 
implementation, seldom and self-community in doing PSN.

The interviewresults with all informants of health personnel and community obtained the results that the success indicator of PSN program was the decrease of incidence rate and crude fatality rate of DHF morbidity and mortality. ABJ increased from last year which only 90\% could reach $>95 \%$, the importance of PSN so as to conduct PSN routinely and voluntarily without any appeal from the government or health workers, and the community was not fogging minded, and the community was not only dependent on health personnel in doing PSN.

Based on the observation results, researcher obtained the result that there were various forms of PSN Program activities that are $3 \mathrm{M}$ Plus, the formation of jumantik cadres, the socialization of dengue involving cross-sector, epidemiological investigation (PE), counseling about PSN conducted by health workers in every meeting of health cadres of PKK in village/ district. PSN activities existed that were prevented and promoted. Preventive PSN activities were jumantik formation, gathered to clean the environment every 2 weeks, and simultaneous jumantik movement.

Based on the interview results with health personnel and policy makers, the result showed that P2 Policy of DHF in Klaten had already had a strong legal organization namely Regional Regulation (Perda) number 32010 on the Prevention and Control of Animal Sourced Disease, where DHF was included in it. With Regional Regulation, itwas expected to strengthen and encourage the successful implementation of PSN Program in Klaten. Based on the interview results with informants, it could be explained that the PSN Program policy communication had been good and there were no significant obstacles.

Communication of PSN Program policy was done in monthly meeting of village health cadre and village midwife in Puskesmas of Klaten and every 3 month meeting between District Health Office and Head of Puskesmas and health worker at Puskesmas handling DBD that was P2 DBD, Promkes, and Kesling.

The interview results with all informants of health personnel and community obtained the result that the obstacles in the implementation of PSN are: public knowledge level that is still less about PSN and the role of public figures had not been maximal, jumantik had not been active in doing PJB, and still lack of health workers who had special duty in PSN Program. The interview results with informants both health workers and the community obtained the result that the community believes PSN effectiveness was ready to prevent DBD although there were a few people who still had lack of confidence in PSN. Another step was to involve crosssector of both village apparatus and community leaders in the implementation of PSN in the community so that people would be more confident in PSN to prevent and overcome DHF.

Regular PSN program implementation should have been done because Aedesaegypti mosquito larvae not only live and breed in the rainy season but also in the dry season, especially the dry season before the rainy season. Results from field observations found that community was not really sure for the first time about PSN Program prevent and control DHF. People still thought that fogging was the best way to deal with dengue fever.

Some efforts to extend and socialize PSN conducted by Health Organization by involving routine and continuous inter- 
Journal of Epidemiology and Public Health (2016), 1(1): 37-48

https://doi.org/jepublichealth.2016.01.01.05

sector last to increase community's confidence in PSN Program to prevent and control DHF although there were a few people who still assumed that DHF could only be overcome by fogging. Informants from the Health Department considered this was a natural thing because there were people who did not really understand about PSN Program and what long term side effects of fogging are. The values that existed in the community towards the implementation of the PSN Program were appropriate and not contrary to the values that exist in the community. A lot of religious values which were in line with the PSN Program especially Islamis taught about cleanliness which is part of faith.

Enabling factor was the number of facilities and health infrastructure facilities sufficient to provide health services to the community, especially in supporting the implementation of PSN Program. Even now all community health center in Klaten have already had laboratory to check patient especially blood test. Based on theinterview results with all the informants of health workers, the result showed that the number of health workers who specifically assigned to handle and supervise the implementation of PSN Program was not ideal, especially the epidemiologist and promkes. However, it did not mean that the shortage of personnel makes PSN program implementation was not running well but the epidemiologist and promkes for PSN was taken from other health workers in the health center either from midwives, nurses, sanitation personnel, public health personnel or other health workers to PSN program to keep running.

The interview results with informants of health personnel and community obtained the results that PSN Program should have obtained support from the government and community because with- out the support of the government and community PSN will not work. The government supports PSN Program by funding and infrastructure while the community supports this program by accepting information about PSN Program and making changes in daily behavior.

Based on the interview results with health personnel and community informants, it could be explained that fund allocation for the implementation of PSN program was not quite ideal, especially at the level of health centers, villages or district. For Puskesmas this PSN program fund was taken from BOK (Health Operational Assistance) fund which in BOK program of PSN program was included in vector control program, socialization and formation of vector hunting cadre. The BOK Fund was not only for PSN program but must be shared with other programs and depends on the priority of the disease in the Puskesmas.

The driving factors include the behavior and attitudes of health workers in this case health workers in Klaten Health Office and puskesmas to encourage the implementation of PSN Program with various activities such as holding cross-sectoral meetings on PSN, Jumantik formation of each village, training on PSN in various mass organizations in Klaten and took several organizations/ communities either scout, PMR or other organizations to be Jumantik cadres in their respective environments.

Based on the interview results with all informants of health personnel and community, it was obtained the result that implementation of policy program of Klaten regency in the effort to overcome the dengue fever is quite good although it was still not maximal. Based on the interview results, it was found that the objectives and policy objectives of Klaten Government in 
encouraging the success of PSN Program are community leaders, government figures at village, kelurahan, kecamatan and kabupaten levels, for the purpose of reducing morbidity (IR) and mortality (CFR) in Klaten District.

Interview results with health personnel informants that the obstacles in policy implementation Klaten Government to tackle DHF was the community's awareness still low in doing PSN, people's behavior were still less in doing PSN regularly, not in the ideal operational fund for jumantik in doing PJB, and health personnel were still not ideal in implementing DHF control policies. Based on the interview results with all informants of health personnel and community obtained the result that not all health personnel informed about POKJANAL DBD, what duties and functions are and how the performance of POKJANAL DBD to do in Klaten. For health personnel informants from Health Department knew and understood about POKJANAL DBD. For informants at the village level, village midwives, community leaders, village heads, Village Health Leaders, Village Coordinators, PKK Chiefs, Jumantik Cadres and villagers did not know about POKJANAL DBD.

This is due to several factors namely lack of information and socialization from either district or village about POKJANAL DBD. The interview results with health personnel informants that barriers for health workers in the implementation of PSN program were the number of health workers are still lacking. The solution for PSN Program obstacles was to generate community commitment to conduct regular PSN by giving counseling and socialization about PSN to overcome DHF, adding budget for PSN Program implementation to be more ideal and adding health worker.
The interview results with informants of health personnel, policy makers and community obtained the result that theoretically all informants know about Jumantik, the volunteers from the surrounding environment who voluntarily want to be responsible for monitoring dengue mosquito Aedes Aegypti DBD in the region and reporting to the village through village midwife regularly. Jumantik should obtain special training and live near the area monitor the mosquito larvae DBD.

Based on the interview results with informants both health workers and the community obtained the result that health workers and community understood the tasks and objectives of forming jumantik that was to perform periodical larvae in the community either once or twice a week and check the water reservoir. Interviews with informants could be explained that jumantik had a good effort to overcome DHF because jumantik did a real action by doing direct community to do PJB in the environment once or twice a week, making recapitulation monitoring larva family to be reported to village through midwife villages once a month, providing sufficient information on DHF and prevention and motivating people to regularly conduct PSN in their respective neighborhoods.

Based on interviews with informants of health and community, the result showed that the attitude and behavior of jumantik in performing the task was quite good. Jumantik was quite friendly and good in behaving to the community. The interview results with health personnel informants obtained the result that PJB was effective to prevent DHF diseases if properly implemented by jumantik and obtain support from community leaders in the environment and PJB results conducted by jumantik then reported to RT, RW, and 
Journal of Epidemiology and Public Health (2016), 1(1): 37-48

https://doi.org/jepublichealth.2016.01.01.05

Midwife Village so there were some followup from RT, RW, or village.

The interview results with all informants obtained the results that it was needed special training for jumantik cadres before carrying out their duties to perform PJB once a week, make reports of monitoring larva family once a month, provide information to the community about preventing DHF, and motivate people to routinely and regularly conduct PSN. Based on the interview results with informants, it was found that jumantik obstacles in carrying out the tasks could be overcome by various solutions such as adding the operational fund for jumantik, puskesmas and village midwife to approach the community leaders, to support the absolute jumantik activities, and to evaluate the results of PJB conducted by jumantik at RT, RW, or village, involving community leaders in approaching community members who refuse their houses are examined by jumantik in order to do, holding community leaders to conduct PJB at home or uninhabited environment, and involving health officers in doing PJB as well as wearing jumantik identification and uniform every time doing the task.

Based on interviews with informants obtained the result that operational funds for jumantikwere still not ideal. It took a lot of money for jumantik both for socialization costs, jumantik cadre formation, and purchasing equipment for jumantik cadres. So far, funds from Klaten for jumantik operational was taken from BOK and APBD, but the amount was still not ideal. For jumantik equipment such as a flashlight of Health Office and Puskesmas it cannot be provided yet.

\section{DISCUSSION}

Effectiveness means ability of choosing objectives and appropriate methods and tools to achieve the goals that have been set. Measuring effectiveness often has difficulty. Difficulties in measuring effectiveness are also due to the achievement of the outcomes are often not known in the short term, but long term after a program ends, so the effective qualitative measurement is usually expressed in forming a judgment such as customer and community satisfaction level (Sulaeman, 2011). Klaten has also issued the regulation No. 32010 on prevention and control of diseases sourced from animals and Klaten Klup Number 5 2013. This is the legal basis in the implementation of PSN Program in Klaten to reduce morbidity rate (IR) DBD and mortality rate (CFR) DBD. Communication of PSN Program policy is delivering information from Klaten Health Office to Head of Health Center and health workers at puskesmas, sub-district head, village and village head, village midwife, community leaders, and health cadres. This is in line with Subarsono's statement (2012) that communication and coordination is one of organization veins so that the programs can be realized according to goals and objectives.

Obstacles of the implementation of PSN program is the behavior of people who have not implemented regular PSN, the community is still fogging minded and has perception that fogging is the most appropriate action to overcome DHF, public knowledge level is still less about the PSN, the role of community leaders has not been maximized by active jumantik yet in doing PJB and lack of health workers in the implementation of PSN Program. This is in line with study Suharti (2010) states that people's behavior in doing PSN is influenced by internal and external factors. People's perceptions which are still thinking that fogging is the right way to overcome DHF is also a barrier in the 
implementation of mosquito nets through eradication program. In fact according to Suroso (2003) $3 \mathrm{M}$ action is the most appropriate way to prevent and control DHF appearance. Predisposing factors manifest in knowledge, attitudes, beliefs, values and so on. This predisposing factor can be as a main factor or as a barrier to community behavior in PSN DBD in Klaten.

According to Lawrence Green, behavior is influenced by three factors: predisposing, enabling and reinforcing factors. In this study, it was found that the knowledge of health workers and policy makers on PSN program is good, but for the community there are some who do not understand about PSN Program to overcome Dengue Fever. This is because community education level and lack of information provided by health cadres in the field.

Lack of public knowledge about the PSN program is community cause which is still fogging minded. People who are still fogging minded assume that DHF can only be overcome by fogging without having to do PSN. This lack of community knowledge is also the reason why people do not conduct routine PSN in their environment. Whereas, the public knowledge about this PSN can be obtained from various information and various sources. Knowledge derives from well-planned and well-structured education, as well as information that is not well structured. The planned education is gained through formal training and education while information is poorly structured through reading newspapers, magazines, daily conversations with their friends and family, listening to the radio, watching television and based on selfexperience (Mantra, 1993).

Community knowledge still lacking about PSN program has an effect on people's behavior in doing PSN in their environment. Non-routine community behavior in PSN resulted in high rate of morbidity (IR) of DBD in Klaten. This is line with Lathu (2012) study states that there is a correlation between community knowledge level about DHF and the behavior of dengue disease prevention and this is also supported by Budi's study (2015) states that there is a correlation between people's knowledge about dengue fever and dengue fever prevention in Dukuh Gunung RT 01 RW 12 Pucangan, Kartasura, Sukoharjo.

Possible factors or enabling factors are factors that influence behavior formation making the motivation basis. This enabling factor may influence direct and indirect behavior depending on its environmental factors (Glanz, et al 2002). Another possible factor in implementing PSN Program is the number of health workers and support from the government and community.

According to Green (1988), human behavior derives from the impulses that exist in man, while encouragement is an attempt to meet the needs that exist in man. Human behavior is a reaction that can be simple or complex. Jumantik is a volunteer from the surrounding environment who volunteers to be responsible to monitor the dengue mosquito, Aedes Aegypti mosquito, in an area and reporting to the village regularly and continuously. The role of jumantik in efforts to control DBD in Klaten District is quite important in reducing the case of DHF.

This study was consistent with Pratamawati (2012), which stated that that the role of jumantik is very important in DHF early awareness system because it serves to monitor the existence and inhibit the early development of DHF dengue vector.

Based on this study, it can be concluded that PSN Program effectiveness 
Journal of Epidemiology and Public Health (2016), 1(1): 37-48

https://doi.org/jepublichealth.2016.01.01.05

in Klaten to overcome dengue fever is quite effective. The role of predisposing factors to PSN Program in efforts to overcome DHF is as the key of PSN Program implementation. Enabling Factors are very important in implementing this PSN Program in the community. The driving force in PSN program has still not been maximal, especially in the implementation of Perda and Perbup on the Prevention and Control of Animal-Source Diseases. The role of jumantik in preventing DHF in Klatenis very important especially for the early awareness of DHF because it serves to monitor the presence and inhibit the early development of vector dengue transmitter.

\section{REFERENCE}

Budi H (2015). Hubungan Tingkat Pengetahuan Warga Tentang Demam Berdarah Dengan Upaya Pencegahan Demam Berdarah di Dukuh Gunung RT 01 RW 12 Desa Puncangan Kecamatan Kartasura Kabupaten Sukoharjo." Kosala” JIK. 3(2): 63.

Cresswell J (2010). Study Design. Yogyakarta: Pustaka Pelajar.

Dinas Kesehatan Kabupaten Klaten (2013). Profil Kesehatan Kabupaten Klaten. Klaten.

(2015). Profil Kesehatan Kabupaten Klaten. Klaten.

Dinas Kesehatan Provinsi Jawa Tengah (2014). Profil Kesehatan Provinsi Jawa Tengah. Semarang: Dinas Kesehatan Provinsi Jawa Tengah.

Direktorat Jenderal Pengendalian Penyakit dan Penyehatan Lingkungan (P2PL) Kementerian Kesehatan Republik Indonesia (2009). Profil pengendalian penyakit dan penyehatan lingkungan. Jakarta: P2PL Kementerian Kesehatan Republik Indonesia

Glanz (2002). Health Behavior and Health Education Theory, Study, and Prac- tice 3rd Edition. United States of America: Jossey Bass a Willey Imprint, Hal: 418

Green LW (1988). Policies For Decentralization And Development Of Health Education. Center For Health Promotion Study And Development.

Kementerian Kesehatan (2010). DBD di Indonesia tahun 1968-2009, Buletin Jendela Epidemiologi: 2. Jakarta.

Lathu F (2012). Hubungan Antara Tingkat Pengetahuan Masyarakat Tentang Penyakit DBD (DBD) Dengan Perilaku Pencegahan Penyakit DBD Di Wilayah Kelurahan Demangan Yogyakarta. Yogyakarta: Stikes Respati Yogyakarta.

Mantra I (1991). Pengantar Studi Demografi. Yogyakarta: Nur Cahaya.

Pratamawati D (2012). Peran Juru Pantau Jentik dalam Sistem Kewaspadaan Dini DBD di Indonesia. Salatiga: Balai Besar Penelitian dan Pengembangan Vektor dan Reservoir Penyakit

Soeparmanto P (2006). Peningkatan penanggulangan penyakit DBD berbasis masyarakat dengan penyuluhan. Berita Kedokteran Masyarakat. 22(2): 75-81.

Subarsono (2012). Analisis Kebijakan Publik (Konsep, teori, dan Aplikasi). Yogyakarta: Pustaka Pelajar.

Suharti S (2010). Hubungan Penobtainahuan Dan Motivasi Dengan Perilaku Kepala Keluarga Dalam PSN DBD (Di Wilayah Kerja Puskesmas Loa Ipuh Kabupaten Kutai Kartanegara). Tesis. Surakarta: Universitas Sebelas Maret.

Sulaeman ES (2011). Manajemen Kesehatan: Teori dan Praktik di Puskesmas. Yogyakarta: Gadjah Mada University Press.

Sulaeman ES (2015). Metode Penelitian Kualitatif dan Campuran: dalam Ke- 
Pradana et al./ The Effectiveness of Mosquito Breeding Site Eradication

sehatan Masyarakat. Surakarta: UNS Press.

Suroso T (2003). Strategi baru penanggulangan DBD di Indonesia. Jakarta: Depkes RI.

Yulianti NS (2007). Pengaruh Keaktifan Juru Pemantau Jentik (Jumantik)
Terhadap ABJ (ABJ) dan Kejadian Demam Berdarah Dengue (DBD) (Studi Pada Pelaksanaan "Gerakan Jumat Berseri+PSN 6o Menit" Di Kota Mojokerto). Tesis. Surabaya: Universitas Airlangga. 